Отримано: 30 квітня 2018 р.

Прорецензовано: 29 травня 2018 р.

Прийнято до друку: 1 червня 2018 р

e-mail: Lena_Gabelko@i.ua

DOI: $10.25264 / 2519-2558-2018-2(70)-19-22$
Habelko O. Formation of readiness of future philologists to professional self-realization. Наукові записки Начіонального університету "Острозька академія»: серія «Філологія». Острог : Вид-во НаУОА, 2018. Вип. 2(70), червень. С. 19-22.

УДК: $378.015 .311(043.5)$

Olena Habelko,

PhD (Candidate of Pedagogical Sciences), Associate Professor

Department of Linguodidactics and Foreign Languages

Volodymyr Vynnychenko Central Ukrainian State Pedagogical University

\title{
FORMATION OF READINESS OF FUTURE PHILOLOGISTS TO PROFESSIONAL SELF-REALIZATION
}

The necessity of formation of readiness of future philologists to complete professional self-realization is determined by increasing requirements to the level of preparation of graduates, by the need for constant professional self-education that ensures competent entering into the labour market. In our opinion, the most significant influence on the formation of readiness for self-realization in a professional field has a set of pedagogical conditions, provided in the training process. In the study we have defined pedagogical conditions of formation of readiness of future philologists for professional self-realization: the actualization of subjective experience of students and its inclusion in the training contents, providing communication between the subjects of the educational process on the basis of dialogical interaction, the formation of attitudes of future philologists to professional self-realization. It has been defined that the efficiency of the process of self-realization is associated with the success of pedagogical activity of the student during pedagogical practice and positive future of professional benchmarks that reveals the possible future career prospects. Having done experimental research, it has been proved that integrated application of certain pedagogical conditions promotes formation of readiness to professional self-realization as a phenomenon in all its aspects.

Key words: self-actualization, professional fulfillment, readiness for professional self-realization, pedagogical conditions, future philologists.

Габелко Олена Миколаӥвна,

кандидат педагогічних наук, доцент кафедри лінгводидактики та іноземних мов

Центральноукрайнський державний педагогічний університет імені Володимира Винниченка

\section{ФОРМУВАННЯ ГОТОВНОСТІМАЙБУТНІХ ФІЛОЛОГІВ ДОПРОФЕСІЙНОЇ САМОРЕАЛІЗАЦІЇ}

Необхідність формування готовності майбутніх філологів до повночінної професійної самореалізачії зумовлена зростаючими вимогами до рівня підготовки випускників, потребою в постійній професійній самоосвіті, шо гарантує компетентне входження їх у ринок праці. Найбільш значимий вплив на формування готовності до самореалізації у професійній сфері, на нашу думку, має сукупність педагогічних умов, забезпечуваних у процесі професійної підготовки. У ході дослідження нами обтрунтовані педагогічні умови формування готовності майбутніх філологів до професійної самореалізачії: актуалізація суб'єктного досвіду студентів і його включення в зміст професійної підготовки, забезпечення комунікачії між суб 'єктами освітнього процесу на основі діалогічної взаємодї̈, формування иіннісних установок майбутніх філологів на професійну самореалізаиію. 3 'ясовано, шо ефективність процесу самореалізаиї пов'язана з успішністю педагогічної діяльності студента в процесі педагогічної практики та позитивними майбутніми професійними орієнтирами, цуо розкриває можливі перспективи кар'єрного зростання. Шляхом експериментального дослідження доведено, шо комплексне застосування визначених педагогічних умов сприяє формуванню готовності до професійної самореалізації як иілісного явищза в усіх його аспектах.

Ключові слова: самореалізація, професійна самореалізація, готовність до професійної самореалізацї, педагогічні умови, майбутні філологи.

Габелко Елена Николаевна,

кандидат педагогических наук, доиент кафедры лингводидактики и иностранных языков

Центральноукраинский государственньй педагогический университет имени Владимира Винниченко

\section{ФОРМИРОВАНИЕ ГОТОВНОСТИ БУДУЩИХ ФИЛОЛОГОВ К ПРОФЕССИОНАЛЬНОЙ САМОРЕАЛИЗАЦИИ}

Необходимость формирования готовности будущих филологов к полноценной профессиональной самореализации обусловлена возрастающими требованиями к уровню подготовки выпускников, необходимости в постоянном профессиональном самообразовании, что гарантирует компетентное вхождения их на рынок труда. Наиболее значимое влияние на формирование готовности к самореализации в профессиональной сфере, по нашему мнению, имеет совокупность педагогических условий, обеспечиваемых в проиессе профессиональной подготовки. В ходе исследования нами обоснованы педагогические условия формирования готовности будущих филологов к профессиональной самореализации: актуализация субъектного опыта студентов и его включение в содержание профессиональной подготовки, обеспечения коммуникации между субъектами образовательного процесса на основе диалогического взаимодействия, формирования ченностных установок будущих филологов на профессиональную самореализаиию. Установлено, что эффективность процесса самореализации связана с успешностью педагогической деятельности студента в процессе педагогической практики и положительными будушими профессиональными ориентирами, раскрывает возможные перспективы карьерного роста. Путем экспериментального исследования доказано, что комплексное применение определенньх педагогических условий способствует формированию готовности к профессиональной самореализации как иелостного явления во всех его аспектах.

Ключевые слова: самореализачия, профессиональная самореализация, готовность к профессиональной самореализации, педагогические условия, будущчие филологи. 
Formulation and justification of the relevance of the problem. The relevance of the problem of self-realization is increasing due to such peculiarities of our society as instability, uncertainty which characterize almost all spheres of human life. In these circumstances the problem of subjective choice of the individual becomes important. The latest structural and substantial changes make a person search for individual solutions of complex issues. These issues are connected with search of oneself, with the definition of their capabilities and desires, their place in the world, that is, the issues that directly determine self-realization, formation of need, ability to see, to explore, to create conditions that will facilitate the transition of self-realization from potential into actual, finding space for the manifestation of self-realization.

Accordingly, the problem of formation of a teacher's identity arises. The teacher appears to be not a performer of institutional, administrative and methodological guidelines and recommendations, but he is a professional, willing and able to go beyond the curriculum requirements, he proves himself to be more versatile, as a multi-faceted personality and he is able to influence the pupils through the uniqueness of his individuality [4, c. 3].

Theoretical and practical solution to the problem of professional preparation of future teachers enforces the need for its improvement, which greatly depends on its orientation to the process of self-realization of students.

Analysis of recent research and publications. The problem of self-realization was highlighted by Y. Andreev, E. Halazhinskyi, V. Hromov, N. Krylova, D. Leontiev, A. Maslow, A. Mudryk, N. Nikitina, K. Rogers, K. Jung and others. In modern science the question of professional self-realization in the conditions of pedagogical activity is investigated in the context of the formation of teacher's personality in the system of higher pedagogical education and training (V. Akimova, H. Hurevich, M. Yevtukh, I. Zaziun, V. Kan-Kalyk, N. Kichuk, N. Kuzmina, L. Mitina, I. Smoliuk, R. Skulskyi, V. Slastyonin, H. Tarasenko, V. Stefurak).

The necessity of formation of readiness of future philologists to full-fledged professional self-realization is determined by increasing requirements to the level of preparation of graduates, the need for constant professional self-education that ensures competent entering them into the labour market.

The willingness of students to different types of activities was investigated by O. Bondarenko, M. Viievska, K. Dolgosh, O. Cernak, L. Sultanova, T. Shestakova and others.

The aim of the study is to define and experimentally check the efficiency of pedagogical conditions of formation of readiness of future philologists to professional self-realization.

The main material of the study. The concept of «self-realization» is one of the central concepts of philosophy, psychology and pedagogical science. Almost all researchers who investigated this problem agree, that of all categories that characterize an individual autonomy, his activity, integrity, intrinsic strength, the category of «self-realization» is the most important.

L. Korostylova [2; 3], considering self-realization to be a necessary attribute of development of an adult, defines this phenomenon as «implementation possibilities of the development of «I» through one's own efforts, co-creation, cooperation with other people (near and remote surroundings), society and the world». Self-realization implies a balanced and harmonious development of different aspects of personality through the application of appropriate measures aimed at disclosure of genetic, individual and personal potentials. In the most general form, self-realization as the process of implementation oneself means the realization of oneself in life and daily activities, search and assertion of one's special way in this world, their values and the meaning of their existence at any given point of time. Self-realization is carried out when a person has a strong stimulating motive for personal development [3, p. 52].

The definition of «self-realization» suggested by N. Pylypenko and A. Artemova deserves much attention. According to their definition «professional self-realization» should be understood as the socialized way of harmonious development of a personality, combined with the obtaining of vocational practical and spiritual experience in the process of acquiring qualification of the future specialist in the period of initial professional development (training in high school) and improvement of professional growth in the process of fulfilling professional roles and responsibilities that are inherent in the disclosure and implementation of personal and professional potential [1].

Readiness in the scientific literature is interpreted as an opportunity of a subject to act at a high level. It is determined as the defining condition of fast adaptation to working conditions, further professional development and training. The analysis of pedagogical literature on the topic of our investigation suggests that readiness is considered as a system of components, of personality traits of future professionals that provide him with the functions adequate to the needs of specific production activities. According to V. Slastyonin, readiness is an integral formation, the core of which is ethical, psychological and informational content operational readiness, which is also one of the key indicators of professional and personal development of the student and specialist.

Formation of readiness, the nature of the process of professional self-realization and its result depend on both internal and external conditions. External conditions make some influence on the internal, thus changing the level of readiness of students to professional self-realization. In our opinion, the most significant influence on the formation of readiness for self-realization in the professional field has a set of pedagogical conditions, which are provided in the training process.

Within a framework of our study, in order to define motives of self-realization in the professional training, the students of the Department of Philology and Journalism of Central Ukrainian Volodymyr Vynnychenko State Pedagogical University (80 people) have been interviewed. The respondents expressed the point of view that the term «self-realization» means the desire to show one's own potential and to meet the professional standards of the teacher-philologist ( $40 \%$ of respondents), the desire to be well prepared to compete $(31 \%)$, interest in professional educational activities, which appeared while studying at school, and the desire to be constantly engaged in self-improvement and self-education $(29 \%)$. The analysis of the study results showed that future philologists are aware of the importance of self-realization. However, $57 \%$ of people were lacking confidence, knowledge about the ways to self-realization associated with the further employment.

For the successful formation of readiness for professional self-realization in the training of future philologists the following pedagogical conditions have been defined.

The first pedagogical condition of formation of readiness of future philologists to professional self-realization is the actualization of the subjective experience of students and its inclusion in the training contents.

The concept of subjective experience is interpreted in different ways, but the difference in semantic interpretations is the desire to describe a particular holistic personality construct, through the prism of which there is assimilation of new knowledge and de- 
velopment of a personality. The functions of the subjective experience in the learning and development lie in the fact that from the perspective of this experience through a kind of selectivity that is ordered by the perception of the information the individual vision of the world is provided. Externally subjective experience shows that the interaction of personality with the surrounding world and internally builds the basis, logic and general orientation of interests, values, worldview [6].

Thus, readiness to professional self-realization will be higher on condition of consideration, not levelling in the educational process of subjective experience, filled with personally-meaningful sense for each person, and the extension of the subjective functions of the students in this process.

The effectiveness of personal self-realization depends on the range of opportunities offered to future teachers in higher educational institutions for the manifestation of their self-sufficiency in learning, scientific and artistic works, diverse themed sections, clubs and special events. However, this orientation can be implemented by constructing an appropriate strategy of the activity of the teacher which creates pedagogical conditions of development of personal self-realization and creativity in system interaction. This interaction is a means of the essential forces of the subjects of education [5, p. 78].

Personal professional development of the subject of labor is possible if he has perceived and experienced the unique system of ideas about himself, his own capabilities and prospects. They create the basis for models and standards of professional aims. As a result, the program of self-development and professional self-realization is formed [5, p. 163].

The second condition is providing communication between the subjects of the educational process on the basis of dialogical interaction.

An important quality of a teacher, communication, is formed, developed on the basis of the needs in communication, one of the main sociogenic (socially conditioned) needs of a person.

The combination of such qualities as reflexivity, flexibility, empathy, communicativeness is formed on the basis of genuine interest to the partner, to his activities, the desire to work together, to participate in a common cause. The ability to cooperate integrates, incorporates comprehensive skills: to articulate point of view, to listen and hear the other person, to investigate the point of view of the partners, to resolve disputes through logical argument, without making logical contradictions of personal relations, to encourage the activity of a partner and to show the initiative timely; to implement emotional and informative support to anyone who needs it in particular; to give another person an opportunity to establish himself, to try hand at various activities; to take the position of another one and to coordinate different points of view, carrying out an exchange of views; choosing dialogue and not monologue; to combine role-playing and interpersonal business and human relationships. The ability to cooperate involves the openness of the teacher and his willingness to any form of interaction.

Taking into account the subjectivity of the student in educational communication and granting him the opportunity to exercise active influence on the learning process increases student's interest in profession, he experiences emotional and value approaching to it, he acquires the possibility of manifestation himself in the profession and growing need for professional growth.

The research shows experimentally that the most effective types of activities which actively develop social and professional communication and influence on intensive development of professional self-realization are: a manifestation of social maturity in communication; active participation in the development of the microenvironment; involvement of fellow students into professional self-development [4, p. 14].

The third condition is the formation of attitudes of future philologists to professional self-realization.

The personality of a teacher is considered in its internal integrity, where professional and personal «I» is closely connected with the system of values. The teacher acts as a person who is focused on the voluntary implementation of certain social and moral functions in the society, as a personality in the full glory of their capabilities and abilities.

The major premise for professional self-realization of a student is his professional direction, which is manifested in accordance with professional attitudes and values. The current positive attitude to the future profession and self-education, a focus on cultural and humanistic values lead to the progressive development and success of future professional activity. The process of progressive personal and professional development of the student can be activated at any stage by creating educational situations, which provide the implementation of the professional role through overcoming depersonalization and changing negative professional attitudes. As a result, it increases self-motivation, promotes student's self-identity through reflexive position, helps to master effective ways of socially responsible behavior, which is transformed into a system of a professional statement [5, p. 75].

The undeniable characteristic of personality that strives for self-realization is the ability to overcome difficulties that arise on the way. Therefore, active protection of their beliefs, values and ideals is the indicator of stress tolerance of the personality that is extremely important, especially in professions of social interaction. In different emergency situations, emotional resilience, realistic approach and well-developed mechanisms of cognitive assessment contribute to flexible response on the basis of the selection of different behavioral strategies in changing social conditions [5, p. 77].

The fulfillment of all conditions in their entirety, in our opinion, to the greatest extent, ensures self-realization of future philologists in the gradual involvement of students in practical-oriented activities during teaching practice. Theoretical training provides mastery of constructing models of educational activities based on program-variable and individual-oriented approach. The unity of theoretical and practical training in the process of pedagogical practice is implemented due to its structure and system construction. Future philologists' ability to fulfill functions of teaching practice (educational, pedagogical, developmental, diagnostic, constructive and communicative) in the process of pedagogical practice indicates readiness for professional self-realization. Phasing implies transformation of educational and personal experience, based on the mastery of pedagogical design and modeling. The process of attracting future philologists to the practically-oriented activities in the process of teaching practice (propaedeutic, folklore, dialectology, educational) contains the following stages: the stage of observing teaching process, modeling of fragments of pedagogical actions, practical implementation of certain educational objectives, creative application of innovative ideas in their own teaching activities [5, p. 164].

The results of experimental studies at Central Ukrainian Volodymyr Vynnychenko State Pedagogical University with the students - the future teachers of philological specialties have shown, that selected set of pedagogical conditions of self-realization of the future teacher, used during the period of teaching practice, allows to increase the level of professional self-realization of students 
on average $60-65 \%$. This means that during the period of teaching practice, two-thirds of the future teachers with a low level of selfrealization in professional activity moved to the group with a high level of self-realization.

Conclusions and prospects for future research directions. Experimental examination of the readiness of future philologists to professional self-realization showed the effectiveness of certain pedagogical conditions, it proves that each of the distinguished pedagogical conditions is necessary for the formation of readiness for professional self-realization as a phenomenon in all its aspects, and their implementation will be reflected in increasing level of readiness of future philologists. In our opinion, the prospect for further research is the study of the effectiveness of professional self-realization of future philologists in extracurricular and educational activities.

\section{References:}

1. Artemova O.I. Profesiina samorealizatsiia osobystosti v suchasnykh umovakh [Elektronnyi resurs] / O.A. Artemova. // Osvita rehionu. - 2010. - \#1. - S. 97-101. - Rezhym dostupu: http://www.social-science.com.ua /.

2. Korostyleva L.A. Problema samorealizatsii lichnosti v sisteme nauk o cheloveke // Psikhologicheskie problemi samorealizatsii lichnosti / Pod red. A.A. Krylova, L.A. Korostylevoi. - SPb., $1997-256$ s.

3. Korostyleva L.A. Psikhologiia samorealizatsii lichnosti: brachno-semeinme otnoshenii / L.A. Korostyleva. - SPb.: Izd-vo S.-Peterb. un-ta, 2000. $-237 \mathrm{~s}$

4. Lebedyk I.V. Pidhotovka maibutnikh uchyteliv inozemnykh mov do profesiinoi samorealizatsii u protsesi vyvchennia fakhovykh dystsyplin : avtoref. dys. na zdobuttia nauk. stupenia kand. ped. nauk: 13.00.04 «Teoriia ta metodyka profesiinoi osvity»/I.V. Lebedyk. Kirovohrad : B.v., 2007. - 18 s.

5. Poseletska K.A. Pidhotovka maibutnikh uchyteliv filolohichnykh spetsialnostei do profesiinoi samorealizatsii: dys..... kandydata ped. nauk: 13.00.04 / Poseletska Kateryna Andriivna. - Vinnytsia, 2016. - 339 s.

6. Ryzhukhina I.Iu. Ispolzovanie subieektnogo opyta uchashchikhsia pri proektirovanii individualnykh obrazovatelnykh programm: avtoref. diss... kand. psikh. nauk. / I.Iu. Ryzhukhina. - Moskva, 2000. - 20 s.

7. Samokhina N.M. Samorealizatsiia osobystosti: sutnisna kharakterystyka / N.M. Samokhina // Visn. Luhan. nats. ped. un-tu imeni Tarasa Shevchenka : Pedahohichni nauky / Mystetska osvita : istoriia, teoriia, praktyka. - 2012. - 10. - S. 149-157.

8. Slastenin V.A. Tekhnologiia professionalno-lichnostnogo razvitiia budushchogo uchitelia, ego gotovnosti k organizatsii vospitatelnogo protsessa v obshcheobrazovatelnom uchrezhdenii / V.A. Slastenin. - M.,1994. $-175 \mathrm{~s}$.

9. Fromm E. Imet ili byt / E. Fromm. - M.: Progress, 1986. -238 s. 